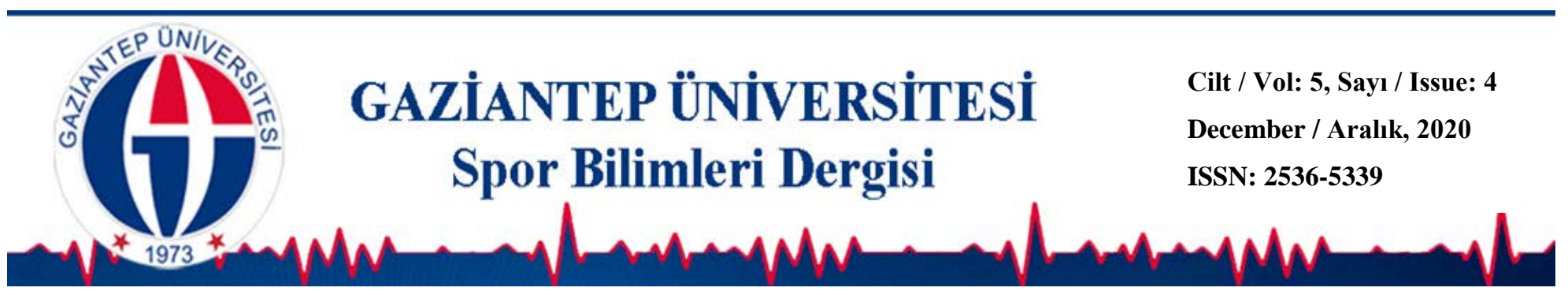

\title{
Spor ve Siyaset Etkileşiminin İncelenmesi: Niğde İli Örneği
}

\author{
Hacı Şükrü TAŞTAN ${ }^{1 *}$ (1) \\ ${ }^{1}$ Niğde Ömer Halisdemir Üniversitesi, Sosyal Bilimler Meslek Yüksekokulu, NİĞDE
}

DOI: 10.31680/gaunjss.764303

Orijinal Makale / Original Article

Geliş Tarihi / Received: 05.07.2020

Kabul Tarihi / Accepted: 19.11.2020

Yayın Tarihi / Published: 14.12 .2020

\section{Öz}

Bu makale ile spor ve siyaset arasındaki etkileşimin akademisyenler ve parti il başkanları yaklaşımından Niğde ili örneğinde incelenmesi amaçlanmıştır. Genel araştırma yöntemlerinden betimsel tarama modelinde gerçekleştirilen bu çalışmanın araştırma grubunu bir, iktidar iki, ana muhalefet partisinin il başkanları ve yardımcıları ile siyaset bilimi akademisyenleri oluşturmaktadır. Verilerin toplanma aracı olarak 9 sorudan oluşan açık uçlu görüşme formu kullanılmıştır. Katılımcıların görüşme sorularına verdiği cevaplardan elde edilen bulgulara göre; siyasilerin, siyaset çevrelerinde sporcu kimliğini ortaya koyması, parti yapısında alanlarında markalaşmış milli sporcuları bulundurması, miting yaptığı yerlerdeki yerel takımın atkısını boynuna takması, stadyumların yaptırımasında maddi destek sağlaması gibi yaklaşımlar, spor ve siyaset arasındaki ilişkinin varlığına örnek olarak gösterilebilir. Araştırma sonucunda katılımcılar genel olarak spor ve siyaset arasında bir etkileşimin varlığını kabul etmektedir. Bununla birlikte bu etkileşimin sadece siyasiler tarafından talep edilmediği, aynı zamanda spor kulüplerinin de amaçları ve çıkarları doğrultusunda siyasilerden destek bekledikleri görülmektedir. Katılımcılar yapılacak destekler, alınacak yardımlar ne olursa olsun, sporun yarışma ruhuna, etiğine aykırı olmamasına, kayırmacılığın yapılmamasına ve rekabet, fair-play, adalet, dürüstlük gibi erdemlilik ifadelerinin önemine dikkat çekmek istemektedir.

Anahtar Kelimeler: Spor, Şiyaset, Etkileşim

\section{Sports and Politics in Turkey Interaction: The Case of Nigde Province}

\begin{abstract}
This research is aimed to be released at Nigde example of the approach, academics and party provincial president of the interaction between sports and politics in Turkey. The research group of this study, which is carried out in the descriptive survey model, which is one of the general research methods, consists of a government, the provincial presidents of two main opposition parties, their assistants and three political science academics. In the collection of the data, the research group's opinions were obtained by applying open-ended interview questions about the factual state of the relationship between sports and politics to the research group. According to the findings obtained in the research; politicians, revealing the identity of athletes in political circles, hosting national athletes in the party structure, gathering the branded names within the party within the party, putting the neck scarf on the neck of the local team at the rally, making the stadiums, examples of the existence of a place such as giving names, taking back and changing names, and the relationship between sports and politics. According to the research result, it can be mentioned that there is a relationship between sports and politics.
\end{abstract}

Keywords: Sport, Politics, Interaction

\footnotetext{
* Sorumlu Yazar: Hacı Şükrü TAŞTAN
}

e-mail: h.sukrutastan@hotmail.com 


\section{Giriş}

Teknolojik ve kültürel gelişmelerle birlikte küreselleşen dünyada spor, bireyler ve örgütler için farkı anlamlar taşımaktadır. Spor, kimileri için insanları biraraya getiren, grup oluşturan, insanlara aitlik duygusu vererek sosyalleşmesini, sosyal hayata katılmasını ve kültürlenmesini sağlayan bir aktivite olurken, kimileri için de yarışma, iş ve serbest zamanlarını değerlendirmek için yapılan eğlenceli zihinsel ve fiziksel aktiviteleri ifade etmektedir (Basım ve Argan, 2009; Yetim, 2011). Başka bir deyişle spor, bedensel ve zihinsel olarak sağlıkı bireyler yetiştirmek ve bireyler arasındaki dayanışmayı, kaynaşmayı ve barışı temin ederek çevreye entegresyonunu sağlamak için yapılan, bireylerin yaşamla mücadele gücünü arttıran faaliyetler bütünüdür (Türksoy, 2010).

Spor bu anlamda büyük kitleler tarafından yapılan veya iletişim araçları ile takip edilen ekonomik ve sosyolojik bir sektör olarak karşımıza çıkmaktadır. Spor, bireylerin yaptığı toplumsal bir aktivitedir. Siyaset ise toplumla ilgilidir. Bu anlamda spor ve siyasetin ortak paydası toplumdur. Her iki kavramda toplumla ilgisi olması sebebiyle spor ve siyasetin etkileşim içerisinde olması beklenebilir. Toplumları yöneten devletlerdir. Devleti yöneten ise siyasetçilerin siyasetidir. Bu kapsamda çok eskilerden günümüze gelen siyaset kavramına baktığımızda, arapça'da yönetmek, eğitmek anlamlarına gelen siyasa kelimesinden dilimize geçtiği görülmektedir. Siyaset dilimizde, "Devlet işlerini düzenleme ve yürütme sanatıyla ilgili özel görüş veya anlayış" olarak tanımlanmakla birlikte, "yönetim sanatı, bilgisı" anlamına gelmektedir (Mardin, 2006; TDK, 2015). Batı dillerindeki söylenişi politika olarak bilinen siyaset kavramı, devlet yönetimini, devlet yönetimi ile ilgi tüm faaliyertleri, devletler arası ilişkileri ve devleti yönetenlerin halkı ile olan ilişkilerini ifade etmektedir. İnsanlığın varoluşundan bu yana siyaset, devlet olma, devleti yönetme, farklılaşma, çatışma, tercih yapma gibi faaliyetler olarak da tanımlanmışıı. Siyaset, insanların biraraya gelerek aynı paydada buluştuğu, gruplar halinde örgütlendiği, toplumsal bir oluşumu ifade etmektedir. Siyasi partiler ise aynı paydada toplanan ve toplumun oylarını alarak biraraya gelen, genel olarak belirli bir ideolojiye sahip örgütleri ifade etmektedir. Toplumla sıklıkla etkileşim içerisinde olan siyasi partiler, günümüzde profesyonelce bir yaklaşımla, modern pazarlama ve reklam teknikleri ile toplumu etkileme (Dursun, 2013), bireyleri taraf olarak yanına çekme, onlardan oy alma, ülkeyi yönetme, çoğunluğu sağlayarak bir güce sahip olmak istemektedir. Siyasi partilerin bu beklentilerini gerçekleştirmek için toplumu ilgilendiren ve toplumun ilgisini 
çeken alanlarda propaganda faaliyetlerinde bulunduğu görülmektedir. Toplumu ilgilendiren ve toplumun ilgisini çeken faaliyetlerden biri olan spor, özellikle de geniş kitleler tarafından oynanan ve takip edilen futbol, siyasilerin seçmenlerine ulaşmalarında kullandıkları bir kanal olabilmektedir.

$\mathrm{Bu}$ anlamda spor ve siyaset kavramlarını biraraya getiren ve ilişkilendiren ortak nokta seçmenlerdir, yani insanlardır. İnsanlar sosyal yaşantısı içerisinde beden ve zihin sağlığını korumak, para kazanmak ve eğlenmek, sosyalleşmek gibi birçok amaçlarını gerçekleştirmek için spor yapmaktadır. Bu sebepten spor toplumlarda önemli bir yere sahip olmaktadır. Spor yapmak isteyen insanların sportif ihtiyaçlarını karşılamak için kurulan spor örgütleri ve popülerliği her geçen gün artan spor endüstrisi, politikadan iş dünyasına, sinemadan, sanata hemen hemen her kesimin katıldığı ekonomik bir sektör olarak karşımıza çıkmaktadır (Ekmekçi, 2016). Ekonomik bir sektör olan spor endüstrisi, günümüzde bireylerin, grupların, kulüplerin, kurum ve işletmelerin, hatta ülkelerin, rekabet içerisinde oldukları, para kazandıkları, sponsorluk aracılığıyla reklam ve pazarlama yaptıkları bir alan olarak görülmektedir (Saatçioğlu, 2012).

Spor ve siyaset ilişkisi artık yadsınamaz bir gerçek olarak karşımıza çıkmaktadır (Chen, Ping ve Hui, 2009). Sporun, modern bir ulusun inşa edilmesinde kısmen sosyal yönünün olduğu kadar ekonomik ve politik yönleri de bulunmaktadır. Diğer politika alanlarında olduğu gibi spor, çeşitli şekillerde toplumun inşa edilmesi için önemli hale gelmektedir (Liu, 2003). Devlet politikalarında spor ile ilgili uygulamalarının bulunması, devletin toplumun fiziksel ve zihinsel sağlığına yönelik düzenlemeler yapması, devletin amaçlarından biridir. Bununla birlikte toplumun sportif faaliyetlerde yoğunlukla yer alması, siyasetin de toplumu ilgilendirmesinden, spor ve siyaset arasındaki etkileşimi beraberinde getirmektedir. Siyasette ilk olarak egemenlik, iktidar, güç ve otorite gibi kavramlar gelmektedir. Bu kavramların anlamında insanlar üzerinde egemen olmak, iktidar olmak, ve otorite kurmak vardır. $\mathrm{Bu}$ açıdan siyasetin konusu ve kavramları, toplumun oluşturduğu kurumları ve örgütleri kapsamaktadır (Dursun, 2013). Kurumları ve örgütleri oluşturan insanları ilgilendiren sporun, toplumsal bir olay olması, siyasetinde toplumsalı konu edinmesi nedeniyle spor ve siyaset etkileşim içerisinde olabilmektedir.

Siyasette, siyasilerin seçmenlerine ulaşmasında o bölgedeki popüler sporları bir araç olarak görülebilmektedir. Bu anlamda günümüzde takım sporları arasında en popüler ve seyirci kitlesi en fazla olan spor dalı futbol (Konter, 2006), yüksek seyirci 
kapasiteleri olan stadyumlarda oynanmaktadır. Futbol maçlarını stadyumda izleyen seyircinin olduğu kadar medya, internet, gazete ve dergiler aracılığıyla her yerde ve her ortamda büyük kitleler tarafından izlenmekte ve takip edilmektedir. Bu denli büyük kitleler tarafından izlenen ve takip edilen bir spor dalı siyasetçiler, kurumlar ve işletmeler tarafından tanıtım aracı olarak kullanılabilmektedir. Futbol, siyasilere temsil ettiği partiyi ve kendisini tanıtması için uygun ortamlar sağlamaktadır. Bununla birlikte siyasi liderlerin tuttukları futbol takımını açıklamaları, o futbol takımının müsabakalarına gitmeleri seçmen davranışını olumlu veya olumsuz etkileyebilmektedir. Ayrıca milletvekillerinin seçim bölgelerindeki futbol takımlarıyla kendilerini özdeşleştirdikleri görülmektedir (Şahin ve İmamoğu, 2011). Seçim dönemlerinde siyasi liderlerin seçmenlerine ulaşmak için ziyaret ettikleri kentlerde mitinglerinde o bölgenin futbol takımlarının atkılarını takmaları bir tesadüf değildir. Bu tarz sportif sembollerle daha geniş bir seçmen kitlesine ulaşarak, marka imajı ile bütünleşerek görsel iletişim yolunu kullanarak mesajlarını iletmek istedikleri değerlendirilmektedir. Bunun yanı sıra partiler emekli olmuş sporu bırakmış olan sporcular parti bünyesine dahil edilerek seçmenine mesajlar vererek popüler görünmek istemektedir.

Bu durum sadece Türkiye'de değil Avrupa'daki diğer ülkelerde de siyasilerin popüleriterliğini arttırmak için sporu kullandıkları görülmektedir (Victor, 2009). Avrupa'da J.F. Kennedy'nin başarılı sporcuları ve takımları telefon ile arayıp tebrik etmesi, İngiliz başbakan Harold Wilson'ın başarılı sporcu ve takımlar için resepsiyon düzenlemesi ve ödüller vermesi, Margaret Thacher'in ingiliz futbol takımları ile fotoğraf çektirmesi ile bu geleneği sürdürmesi bu durumu gösteren önemli örneklerdendir (Houlihan, 1991). Ayrıca dış siyasette etken rol oynayan İngiltere gibi önemli ülkelerin kendi spor alışkanlıklarını gittikleri ülkelere de götürerek örnek teşkil edecek şekilde bu sporları yaygınlaşmaya çalıştıkları görülmektedir (Arnauld ve Riorden, 2006).

Popüler spor dalları siyasiler, ünlü kişiler, medya ve magazin dünyası tarafından da ilgi ile takip edilmektedir. Nitekim tanınan kişilerin fitness salonunda çalışırken, yürüyüş yaparken, basketbol oynarken, tenis oynarken, koşarken görüntülenmesi, mecliste düzenlenen futbol turnuvası, sporun toplum nezdinde önemi vurgulanırken, kişileride olumlu yönde tanıtmaktadır. Buradan yola çıkarak spor ve siyasetin karşılıklı olarak biribiri ile etkileşim içerisinde oldukları değerlendirilebilir. İnsan topluluklarının davranışlarını inceleyen bilim dalı sosyoloji de 
sosyal hayat içinde ortaya çıkan bu toplumsal etkileşimi çözümleme gayreti gösterir. Siyaset toplumların siyasi davranışlarını ve siyasi tercihlerini etkileyen değişkenleri inceleyen bir bilim dalıdır (Alkan, 2018). Bu anlamda bireylerin siyasal tercihlerinin belirlenmesinde sosyalleşmenin rolü, sosyalleşme faaliyetleri içerisinde de yer alan spor ile siyasal sosyalleşme bu etkileşim içerisinde seçmenlerin tercihlerini etkileyebilmektedir. Spor ve siyaset ilişkisi, siyasilerin seçmenlerin tercihlerini etkileme açısından, spor kulüplerinin menfaatleri doğrultusunda siyasetten beklentileri açısından önemlidir.

Bu makalede spor ve siyaset arasındaki etkileşimin akademisyenler ve parti il başkanları yaklaşımından Niğde ili örneğinde incelenmesi amaçlanmıştır. Bu kapsamda Niğde ilinde bulunan üç siyasi parti liderleri ve Niğde Ömer Halisdemir Üniversitesi Siyaset Bilimi ve Uluslararası İlişkiler bölümünde görevli öğretim üyeleri ile görüşmeler yapılmıştır. Ayrıca bu alanda yayınlanmış ulusal ve uluslarası dergiler, makaleler literatür taraması yapılarak incelenmiştir.

\section{Yöntem}

\section{Araştırmanın Modeli}

Spor ve siyaset arasındaki etkileşimin incelendiği bu çalışmada, nitel araştırma metodolojisi içinde yer alan genel tarama modellerinden betimsel tarama modeliyle gerçekleştirilmiştir. Betimsel tarama modelinde var olan bir durum, olgu, olay, tutum gibi vakalar ortaya konur. Spor ve siyaset ilişkisinin incelendiği çalışmada literatür taraması ve görüşmeler yapılmıştır. Literatür taraması, araştırma probleminin belirlenerek anlaşılmasına ve araştırmanın tarihsel bir perspektife oturtulmasına yardımcı olur (Karasar, 2006).

Nitel araştırmalarda veri elde etmek için gözlem, görüşme ve döküman incelemesi yöntemleri sıklıkla kullanılmaktadır. Görüşme daha önce araştırma sorunu ile ilgili yapılandırımış veya yapılandırımamış açık uçlu sorulardan oluşan, araştırma sorunu hakkında veri toplama tekniğidir (Gürbüz ve Şahin, 2018).

\section{Evren ve Örneklem}

Araştırma Niğde ili ile sınırlandırılmıştır. Araştırmaya, Türkiye Büyük Millet Meclisi'nde (TBMM) en fazla milletvekili ile temsil edilen üç partinin il başkanları örneklem olarak alınmıştır. 2015 yılı seçimleri sonucu Adalet ve Kalkınma Partisi (AKP)317, Cumhuriyet Halk Partisi (CHP) 132, Milliyetçi Hareket Partisi (MHP) 42, 
milletvekili ile temsil edilmektedir. Bu da TBMM'nin 550 milletvekilinin 491'ni $\% 89,27$ 'sini ifade etmektedir.

Görüşme, bizzat araştırmacının kendisi tarafından, Niğde ili içerisinde bulunan ve meclisin \% 89,27'sini oluşturan AKP, CHP, MHP il başkanları ve başkan yardımcıları ile Niğde Ömer Halisdemir Üniveristesi Siyaset Bilimi öğretim üyeleriyle yapılmıştır.

\section{Verilerin Toplanması}

Veri toplama aracı olarak nitel araştırmalarda insanlar ile olaylar arasında ilişki durumlarını belirlemek için sıklıkla kullanılan görüşme yöntemi kullanıımıştır. Ayrıca görüşme sorularına ek olarak literatürde yer alan spor ve siyaset alanında basılı ve elektronik kaynaklardan da faydalanılarak veriler toplanmıştır. Bu kapsamda spor ve siyaset etkileşimin varlığını belirlemek için siyasi partilerin parti tüzükleri incelenmiştir. Araştırmada kullanılmak üzere spor ve siyaset olgusal durumu ve tutum yapısını belirlemek için hazırlanan 9 adet açık uçlu sorudan oluşan spor ve siyaset görüşme formu katıımcılara uygulanarak veriler toplanmıştır.

\section{Verilerin Analizi}

Görüşme kayıtlarından elde edilen verilerin kıymetlendirilmesi ve karşıllaşııııması için içerik analizi yöntemi kullanılabilir (Altunışık, Coşkun, Bayraktaroğlu ve Yıldıım, 2012). Bu analiz yönteminde, önceden belirlenen kavramlara ilişkin yazılı, görsel veya işitsel materyal incelenerek bazı tekrar eden kavramlar tespit edilmeye çalışılabilir (Nakip ve Yaraş, 2017). Bu şekilde amaç, toplanan verileri anlamlandırıması, birbirine benzeyen verilerin gruplandırılması ve belirli kavramlarla ilişkilerine ulaşılarak yorumlanmasıdır (Yıldırım ve Şimşek, 2006).

$\mathrm{Bu}$ kapsamda, görüşme sorularına verilen cevapların gruplandıııması ve yorumlanması için içerik analizi yöntemi kullanılmıştır. Araşıımada, TBMM de en çok temsil oranına sahip üç (3) parti (AKP, MHP, CHP) il başkanları ile Niğde Ömer Halisdemir Üniversitesi Siyaset Bilimi Akademisyenleri olmak üzere dört (4) grup bulunmaktadır (Tablo-1). Araşıırmada bu katılımcıların görüşme sorularına verdiği cevaplar Microsoft Exel programı kullanılarak gruplandırılmış ve yorumlanmıştır. 
Tablo 1. Katılımcıların Gruplandırıması

\begin{tabular}{lll}
\hline Grup Numaraları & Grup İsimleri \\
\hline 1. & Grup & AKP il Başkanı \\
\hline 2. & Grup & MHP İ Başkanı \\
\hline 3. & Grup & CHP İ Başkanı \\
\hline 4. & Grup & Siyaset Bilimi Akademisyenleri \\
\hline
\end{tabular}

\section{Bulgular}

$\mathrm{Bu}$ bölümde katılımcıların spor ve siyaset arasındaki etkileşimin varlığını belirlemeye yönelik hazırlanan görüşme sorularına verdiği cevaplar değerlendirilmiştir. Görüşme sorularına katılımcıların verdiği cevaplardan elde edilen bulgular Tablo 1'de özetlenmiştir.

Tablo 2. Katılımcıların Görüşme Sorularına Verdiği Cevaplardan Elde Edilen Bulgular

\begin{tabular}{ll}
\hline $\begin{array}{c}\text { Sıra } \\
\text { No }\end{array}$ & Görüşme Sorusu
\end{tabular}

1. Siyasilerin seçmenlerine ulaşmasında Dört grupta, siyasilerin bu tarz sembollerle daha sporun etkisi var mıdır? $\quad$ geniş bir seçmen kitlesine kolay yoldan mesaj verdiklerini düşündükleri görülmektedir.

Dört grupta, sporu seçmene ulaşmada bir araç

2. Siyasiler sporu seçmenlerine ulaşmak olarak görmektedirler. Halkın toplandığı bu için bir araç olarak görüyorlar mı? alanlarda seçmenle spor vesilesiyle bir araya geldiklerini düşündükleri görülmektedir.

Dört grupta, spor başarılarında siyasetçilerin de

3. Spor başarılarının yanında siyasetçilerin anılması siyasilerin toplum nezdindeki imajına anılması siyasi bir reklam mıdır? olumlu katkı sağlayacağı, başarılı sporcunun ya da takımların yanında yer almalarının kendilerini de başarılı göstereceği düşündükleri görülmektedir.

Dört grupda, genel olarak katıımcıların rutin parti

4. Parti il başkanı olarak ne gibi sportif işlerinden spora ayıracak vakitlerinin bulunmadığı faaliyetleri içerisinde yer alıyorsunuz? ya da diğer parti etkinliklerine katılım eğiliminin daha fazla olduğunu düşündükleri görülmektedir.

Parti olarak spor etkinliklerine parti

5. üyelerinizin katıımını teşvik ediyor Dört grupta, teşvik ettiklerini vurgulamıştır. musunuz?

Illinizde spor salonu veya stadyumlarda

6. düzenlenen spor müsabakalarına, sporu Dört grupta, katıımcıların programları ve düzenlenen spor müsabakalarına, sporu yoğunlukları müsaade ettiği ölçüde spor
sevdiğiniz için mi yoksa siyasi kimliğiniz
müsabakalarına katıldıkları belirtilmiştir. gereği mi katılıyorsunuz?

Parti tüzüğünü/programını inceledim ve

7. partinizin tüzüğünde sporla ilgili konulara yer verilmiş / verilmemiş bu konu hakkında ne düşünüyorsunuz?

Dört grupta, spor ile ilgili düzenlemelerinin olduğunu, partilerin gençlik kolları olduğundan bu konuda daha duyarlı olduklarını vurgulamaktadır.

Dört grupta, siyaset sporu kullanırken bazen de

8. Sizce spor ve siyaset arasında bir ilişki spor alanında rekabet eden aktörler kendi çıkarları var mıdır? adına siyasete yakın durmaya ve siyasi gücü kendi lehine kullanmaya çalıştıklarını düşündükleri 
Taştan, H.Ş. (2020). Spor ve Siyaset Etkileşiminin İncelenmesi: Niğde İli Örneği. Gaziantep Üniversitesi Spor Bilimleri Dergisi, 5(4), 499-518.

olarak görüldüğü dile getirilmiştir. Siyasiler halkın toplandığı bu alanlarda seçmenlerle spor vesilesiyle bir araya geldiklerini düşünmektedir.

Tablo 4. Katılımcıların Siyasilerin Seçmenlerine Ulaşmada sporu bir araç olarak görmelerinin Değerlendirmesi

\begin{tabular}{lll}
\hline & Gruplar & Grupların Verdiği Cevaplar \\
\hline 1. & Grup & Siyasilerin seçmenlerine ulaşmakta sporu bir araç olarak görmektedir. \\
\hline 2. Grup & $\begin{array}{l}\text { Yerel yönetimlerin yönetiminde hangi parti var ise o partilerin bölgelerindeki spor } \\
\text { etkinliklerini, siyasetçiler sporu seçmene ulaşmada bir araç olarak görmekle birlikte } \\
\text { kendi üyeleri tarafından düzenlemesi sebebiyle partilerin bu durumu kendi lehlerinde } \\
\text { daha etkin olarak kullandıkları, spor başarılarını belediye yönetimlerinin başarısı olarak } \\
\text { görüldüğü dile getirilmiştir. }\end{array}$ \\
\hline
\end{tabular}

3. Grup Siyasilerin seçmenlerine ulaşmakta sporu bir araç olarak görmektedir.

4. Grup Siyasilerin seçmenlerine ulaşmakta sporu bir araç olarak görmektedir.Siyasilerin seçmenlerine ulaşmak için katıldıkları mitinglerde yerel halkın takımının atkısını boyunlarına takarak bunu gerçelştirdikleri dile getirimiştir.

Üçüncü soruda, spor başarılarının yanında siyasetçilerin anılması siyasi bir reklam olarak görülmesi sorusuna, katılımcılar spor başarılarının yanında siyasetçilerin anımasını siyasi bir reklam olarak gördüklerini ifade etmektedir (Tablo 5). Seçmenlerin bu tür başarıların siyasiler tarafından önemsenmesini ve desteklenmesini başarıların artması yönünde olumlu bir yaklaşım olarak algıladığı görülmüştür. Spor başarılarında siyasetçilerin de anılması siyasilerin toplum nezdindeki imajına olumlu katkı sağlayacağı, başarılı sporcunun ya da takımların yanında yer almalarının kendilerini de başarılı göstereceği, özellikle milli duyguların yüksek olduğu, milli başarılardaki başarının medyada tanıtılarak ödüllendirilmesi, spor camiası tarafından teşvik edici, toplum nezdinde bu başarının siyasiler tarafından ödüllendirilmesinin, siyasi partilerin imajına olumlu yönde katkı sağlayacağı, bu tür siyasi partilere büyük kitlelerin sempati duyacağı düşünülmektedir. 
Taştan, H.Ş. (2020). Spor ve Siyaset Etkileşiminin İncelenmesi: Niğde İli Örneği. Gaziantep Üniversitesi Spor Bilimleri Dergisi, 5(4), 499-518.

Tablo 5. Katıımcıların Spor Başarılarının Yanında Siyasetçilerin Anıımasını Siyasi

Bir Reklam Olarak Gördüklerini Değerlendirmesi

\begin{tabular}{|c|c|}
\hline Gruplar & Grupların Verdiği Cevaplar \\
\hline 1. Grup & $\begin{array}{l}\text { Başarılı sporcunun ya da takımların yanında yer almalarının sporculara destek } \\
\text { olmak amacı ile sporculara sağlayacağı katkı önemli olarak değerlendirilmektedir. } \\
\text { Ayrıca katıımcı bunu siyasi yaklaşımlarının bir göstergesi olarak görmektedir. }\end{array}$ \\
\hline 2. Grup & $\begin{array}{l}\text { Spor başarılarının yanında siyasetçilerin anıımasını siyasi bir reklam olarak } \\
\text { gördüklerini ifade edilmiştir. . Spor başarılarında siyasetçilerin de anılması } \\
\text { siyasilerin toplum nezdindeki imajına olumlu katkı sağlayacağı değerlendirilmiştir. }\end{array}$ \\
\hline 3. Grup & $\begin{array}{l}\text { Spor başarılarının yanında siyasetçilerin anılmasını siyasi bir reklam olarak } \\
\text { gördüklerini ifade edilmiştir. }\end{array}$ \\
\hline 4. Grup & $\begin{array}{l}\text { Bu tür yaklaşımların siyasi partilere büyük kitlelerin sempati duyacağı } \\
\text { düşünülmektedir. Bu sebeple spor başarılarının yanında siyasetçilerin anılmasını } \\
\text { siyasi bir reklam olarak gördüklerini ifade edilmiştir. }\end{array}$ \\
\hline \multicolumn{2}{|r|}{ Dördüncü soruda, parti il başkanı olarak ne gibi spor faaliyetleri içerisinde yer } \\
\hline \multicolumn{2}{|r|}{ na, il başkanlarının spor eğilimleri, ilgi alanları ile doğru orantılı ola } \\
\hline \multicolumn{2}{|c|}{ erçekleştiği belirtilmektedir (Tablo 6). Genel olarak katılımcıların rutin parti işlerinden } \\
\hline \multirow{2}{*}{\multicolumn{2}{|c|}{$\begin{array}{l}\text { spora ayıracak vakitlerinin bulunmadığı ya da diğer parti etkinliklerine katılım } \\
\text { eğiliminin daha fazla olduğu değerlendirilmektedir. Düğüne, cenezaye, davetlere }\end{array}$}} \\
\hline & \\
\hline \multicolumn{2}{|c|}{ atılmak gibi, bunun yanısıra il spor aktiviteleri belediyeler tarafından düzenlendiği } \\
\hline \multicolumn{2}{|c|}{$\mathrm{n}$, belediye hangi parti yönetiminde ise o parti yönetimi tarafından katılım } \\
\hline
\end{tabular}

Tablo 6. Katıımcıların Parti İ Başkanı Olarak Ne Gibi Spor Faaliyetleri İçerisinde Yer Aldıkları Değerlendirmesi

\begin{tabular}{lll}
\hline Gruplar & \multicolumn{1}{c}{ Grupların Verdiği Cevaplar } \\
\hline 1. Grup & $\begin{array}{l}\text { Rutin parti işlerinden spora ayıracak vakitlerinin bulunmadığı ya da diğer parti } \\
\text { etkinliklerine katılım eğiliminin daha fazla olduğu değerlendirilmektedir. }\end{array}$ \\
\hline 2. Grup & Spor eğilimleri, ilgi alanları ile doğru orantılı olarak gerçekleştiği belirtilmektedir \\
\hline 3. Grup & $\begin{array}{l}\text { Bunun yanısıra il spor aktiviteleri belediyeler tarafından düzenlendiği için, belediye } \\
\text { hangi parti yönetiminde ise o parti yönetimi tarafından katılım sağlanarak, bu } \\
\text { konuda avantaj sağladığı düşünülmektedir. }\end{array}$ \\
\hline
\end{tabular}

4. Grup Siyasi partiler toplumla beraber olmak anlamında sporun içerisinde yer almalıdır.

Beşinci soruda, siyasi parti olarak spor etkinliklerine parti üyelerinin katılımını teşvik edilmesi sorusuna, katııımcılar "Evet, tabiki" olarak cevaplamıştır (Tablo 7). Sporun birleştirici, kaynaştırıcı ve sosyal ilişkileri güçlendirici yönü bilinmektedir. 
Taştan, H.Ş. (2020). Spor ve Siyaset Etkileşiminin İncelenmesi: Niğde İli Örneği. Gaziantep Üniversitesi Spor Bilimleri Dergisi, 5(4), 499-518.

Tablo 7. Katılımcıların Siyasi Parti Olarak Spor Etkinliklerine Parti Üyelerinin Katııımını Teşvik Edilmesi Sorusunun Değerlendirmesi

\begin{tabular}{|c|c|}
\hline Gruplar & Grupların Verdiği Cevaplar \\
\hline 1. Grup & Spor etkinlikleri parti üyelerinin katılımlarının desteklendiği ifade edilmiştir. \\
\hline 2. Grup & İlde spor etkinlikleri parti üyelerinin katılımlarının sağlanması desteklenmektedir \\
\hline 3. Grup & Spor etkinlikleri parti üyelerinin katılımları desteklenmektedir. \\
\hline 4. Grup & Sportif faaliyetler düzenlenmeli, projeler yapılmalı ve uygulanmalıdır. \\
\hline
\end{tabular}

Altıncı soruda, ilinizde düzenlenen spor müsabakalarına sporu sevdikleri için mi yoksa siyasi kimliğinin gereği için mi katılıklarını öğrenmek için sorulan soruya, katılımcıların programları ve yoğunlukları müsade ettiği ölçüde spor müsabakalarına katıldıklarını, bazı durumlarda katıımcılar ise ilde bulunan spor takımları mevcut belediye yönetiminde olduğu gerekçesiyle pek fazla iştirak edemediklerini ifade etmiştir (Tablo 8). Başarıları da belediyeye ait olarak düşünüldüğünden belediyeler hangi partiye ait ise spor etkinlikleride o partinin himayesinde gerçekleştiği belirtilmiştir.

Tablo 8. Katılımcıların İlinizde Düzenlenen Spor Müsabakalarına Sporu Sevdikleri İçin mi? Yoksa Siyasi Kimliğinin Gereği İçin mi? Katıldıklarını Öğrenmek İçin Sorulan sorunun Değerlendirmesi

\footnotetext{
Gruplar Grupların Verdiği Cevaplar

1. Grup Programları ve yoğunlukları müsade ettiği ölçüde spor müsabakalarına katıldıkları, bazı durumlarda ise diğer programlarına katılmaları nedeni ile katılamadıkları ifade edilmiştir.

2. Grup İlde bulunan spor takımları mevcut belediye yönetiminde olduğu gerekçesiyle pek fazla iştirak edemediklerini ifade edilmiştir.
3. Grup İlde bulunan takımların ve sporcuların başarıları o belediye yönetiminde bulanan partiye ait olarak düşünüldüğünden belediyeler hangi partiye ait ise spor etkinlikleride o partinin himayesinde gerçekleştiği belirtilmiştir.
4. Grup Genel olarak siyasiler bazen spor eğilimleri yönünde katılım gösterirken bazen de siyasi yaklaşımlarından dolayı bu tür spor organizasyonlarına katılmaları siyasi reklamları için önemli olmaktadır.

Yedinci soruda, parti tüzüğü/programı incelendiğinde ve parti tüzüğünde /programında sporla ilgili yer verilme durumu ile ilgili soruya, katılımcılar, partilerin gençlik kolları olduğundan spor ile ilgili düzenlemelerinin olduğunu, bu konuda duyarlı olduklarını vurgulamaktadır (Tablo 9). Gençlik kolları olmayan partiler ise bu konudaki çalışmalarının gençlik kollarının olmadığını ancak bu konuda derneklerde, vakıflarda
} 
Taştan, H.Ş. (2020). Spor ve Siyaset Etkileşiminin İncelenmesi: Niğde İli Örneği. Gaziantep Üniversitesi Spor Bilimleri Dergisi, 5(4), 499-518.

bu türlü faaliyetlerinin yürütüldüğünü ve yönetmeliklerinde bulunduğunu beyan etmiştir. Bu konuda kendilerinin de sıklıkla sportif faaliyetler düzenlediklerini vurgulamıştır.

Tablo 9. Katılımcıların Parti Tüzüğü/Programı İncelendiğinde Ve Parti Tüzüğünde /Programında Sporla İlgili Yer Verilme Durumu İle İlgili Sorunun Değerlendirmesi

\begin{tabular}{ll}
\hline Gruplar & Grupların Verdiği Cevaplar \\
\hline 1. Grup & $\begin{array}{l}\text { Parti Tüzük ve programlarında sporla ilgili faaliyetlere yer verdiklerini, sporun toplumun, } \\
\text { bireylerin zihinsel ve fiziksel gelişimene sağladığı katkının farkında oldukları ifade edilmiştir. }\end{array}$ \\
\hline 2. Grup & $\begin{array}{l}\text { Partilerin gençlik kolları olduğundan spor ile ilgili düzenlemelerinin olduğunu, bu } \\
\text { konuda duyarlı olduklarını vurgulamaktadır. }\end{array}$ \\
\hline 3. Grup & $\begin{array}{l}\text { Gençlik kollarının olmadığını ancak bu konuda derneklerde, vakıflarda bu türlü } \\
\text { faaliyetlerinin yürütüldüğünü ve yönetmeliklerinde bulunduğunu beyan etmiştir. }\end{array}$ \\
\hline
\end{tabular}

4. Grup Parti programlarında tüziklerinde spor ile ilgili etkinliklerin bulunması gerektiği belirtilmiştir.

Sekizinci soruda, Spor ve siyaset arasındaki ilişkinin varlığına yönelik soruya katılımcılar, spor ve siyaset arasında bir ilişkinin varlı̆ı̆ından kolayca söz edebilmektedir (Tablo 10). Parti liderleri dönemlerinde elde edilen sportif başarıları sahiplenmekte ve seçmenlerini etkilemekte kullandıkları düşünülmektedir. Kitleleri peşinden sürükleyen spor müsabakaları toplumu ilgilendiren her alanla olduğu gibi siyasetle doğrudan bir ilişkisi söz konusudur. Hatta bazen ülkedeki siyasi münakaşalar ve rekabetler spor sahalarına doğrudan yansıyabilmektedir. Günümüzde futbol endüstriyel yönünden dolayı büyük paraların döndüğü bir sektör haline gelmiş ve ülke ekonomisinin içinde önemini gittikçe arttırmıştır. Bu durum, siyaset ile spor arasındaki karşılıklı ilişkinin yoğunlaşmasına yol açmaktadır. Öyle ki bazen siyaset sporu kullanırken bazen de spor alanında rekabet eden aktörler kendi çıkarları adına siyasete yakın durmaya ve siyasi gücü kendi lehine kullanmaya çalışabilmektedir. 
Taştan, H.Ş. (2020). Spor ve Siyaset Etkileşiminin İncelenmesi: Niğde İli Örneği. Gaziantep Üniversitesi Spor Bilimleri Dergisi, 5(4), 499-518.

Tablo 10. Katıımcıların Spor ve Siyaset Arasındaki İlişkinin Varlığına Yönelik Sorunun Değerlendirmesi

\begin{tabular}{lll}
\hline Gruplar & Grupların Verdiği Cevaplar \\
\hline 1. Grup & $\begin{array}{l}\text { Parti liderleri dönemlerinde elde edilen sportif başarıları sahiplenmekte ve seçmenlerini } \\
\text { etkilemekte kullandıkları düşünülmektedir. }\end{array}$ \\
\hline 2. Grup & $\begin{array}{l}\text { Kitleleri peşinden sürükleyen spor müsabakaları toplumu ilgilendiren her alanla olduğu } \\
\text { gibi siyasetle doğrudan bir ilişkisi söz konusudur. }\end{array}$ \\
\hline 3. Grup & $\begin{array}{l}\text { Günümüzde futbol endüstriyel yönünden dolayı büyük paraların döndüğü bir sektör } \\
\text { haline geldiğini ve ülke ekonomisinin içinde önemini gittikçe arttığını, bu durum, siyaset } \\
\text { ile spor arasındaki karşılıklı ilişkinin varlığının göstergesidir. }\end{array}$
\end{tabular}

4. Grup Spor ve siyaset arasında bir ilişkinin varığından kolayca söz edebilebilir.

Dokuzuncu soruda, Sporda siyaset olmalı mıdır? Sorusuna, katılımcılar "sporda siyaset olmamalıdır" gibi net bir davranış sergilemişlerdir (Tablo 11). Ancak spor ve siyasetin çıkarları doğrultusunda her iki tarafın biribirlerinden yararlandığını, diğer bir ifadeyle bu durumun her iki tarafada yararlar sağladığı ifade edilmektedir. Bu durumda marjinal parti gruplarının karşıtlık oluşmasına yol açmakta bu doğrultuda spor alanında görevli kişilerin parti kişilikleri sorgulanmaktadır. Sporun ruhuna, ahlakına zarar verecek, rekabet ve yarışma heyecanını ortadan kaldıracak adaletsiz yaklaşmılara hiçbir zaman müsaade edilmemesi gerektiği parti liderleri tarafından vurgulanmıştır.

Tablo 11. Katılımcıların, Sporda siyaset olmalı mıdır? Sorusunun Değerlendirmesi

\begin{tabular}{ccl}
\hline \multicolumn{2}{c}{ Gruplar } & \multicolumn{1}{c}{ Grupların Verdiği Cevaplar } \\
\hline 1. Grup & $\begin{array}{l}\text { Sporda siyaset olmamasının gerektiği, sporun yarışma ruhuna ve heyecanını ortadan } \\
\text { kaldıracak yaklaşmıların yanlış olduğu dile getirlmiştir. }\end{array}$ \\
\hline 2. Grup & $\begin{array}{l}\text { Sporda siyaset olmamalıdır. Ancak spor ve siyasetin çıarları doğrultusunda her iki } \\
\text { tarafın biribirlerinden yararlandığını, diğer bir ifadeyle bu durumun her iki tarafada } \\
\text { yararlar sağladığı ifade edilmektedir. }\end{array}$ \\
\hline 3. Grup & $\begin{array}{l}\text { Sporda siyaset olmamalıdır. Sporun ruhuna, ahlakına zarar verecek, rekabet ve } \\
\text { yarışma heyecanını ortadan kaldıracak adaletsiz yaklaşmılara hiçbir zaman müsaade } \\
\text { edilmemelidir. }\end{array}$ \\
\hline 4. Grup & $\begin{array}{l}\text { Spor ve siyasette her iki tarafta bazı durumlarda çıkarları doğrultusunda partisine } \\
\text { yada spor kulübüne yarar sağlamak adına yaklaşım gösterebilmektedir. Ancak bunun } \\
\text { sporun ruhuna, ahlakına zarar verecek, rekabet ve yarışma heyecanını ortadan } \\
\text { kaldıracak adaletsiz yaklaşmılara hiçbir zaman müsaade edilmemelidir. }\end{array}$ \\
\hline Ayrıca spor ve siyaset etkileşimin varlığını belirlemek için siyasi partilerin parti
\end{tabular}

tüzükleri incelenmiştir. Bu kapsamda parti tüzükleri tarandığında AKP tüzüğü 678 sayfadan, CHP tüzüğü, 140 sayfadan, MHP tüzüğü, 161 sayfadan oluşmaktadır.

AKP parti tüzüğünde spora yer verildiği görülmüştür. AKP parti tüzüğünde alt birimlere parti üyelerine veya halka yönelik sosyal, sanatsal ve sportif etkinlikler 
Taştan, H.Ş. (2020). Spor ve Siyaset Etkileşiminin İncelenmesi: Niğde İli Örneği. Gaziantep Üniversitesi Spor Bilimleri Dergisi, 5(4), 499-518.

düzenlemek ile ilgili görevler yüklediği görülmüştür. Parti tüzüğündeki gençlik ve spor ile ilgili belirtilenler şöyle sıralanabilir (AKP Parti Tüzüğü, 2015).

- "Devlet, istiklâl ve Cumhuriyetimizin emanet edildiği gençlerin müsbet ilmin ışığında, Atatürk ilke ve inkılâpları doğrultusunda ve Devletin ülkesi ve milletiyle bölünmez bütünlüğünü ortadan kaldırmayı amaç edinen görüşlere karşı yetişme ve gelişmelerini sağlayıcı tedbirleri alır.

- Devlet, gençleri alkol düşkünlüğünden, uyuşturucu maddelerden, suçluluk, kumar ve benzeri kötü alışkanlıklardan ve cehaletten korumak için gerekli tedbirleri alır."

- Dünyanın ve Türkiye'nin gelişen ve değişen şartları dikkate alınarak yeni bir spor politikası oluşturulacaktır. Spor hizmetleri ağırlıklı olarak yerel yönetimlere bırakılacaktır.

- Amatör ve profesyonel spor klüplerine yerel yönetimlerin daha fazla kaynak ayırabilmeleri için gerekli yasal düzenlemeler yapılacaktır.

- Uluslararası başarılara imza atan sporculara ve kulüplere yönelik destekler artırılarak devam ettirilecektir. Lisanslı sporcuların sosyal güvenlik hizmetlerinden yararlanmalarına imkan tanınacaktır.

- Engelli gençlerin sportif ve sosyal etkinliklere katılımlarını sağlayan projeler uygulamaya konulacaktır.

- Sporcu yetiştiren eğitim kurumları, teşvik edilecektir.

- Toplumu spor yapmaya özendirecek kampanyalar devamlılı ilkesi gözetilerek gerçekleştirilecek, gençler öncelikli hedef kitle olacaktır. Sporcu olmak isteyen genç yetenekler, ekonomik ve sosyal yönden desteklenecektir.

- Spor faaliyetleri özellikle medya eliyle birkaç yaygın spor dalı üzerine odaklanmakta ve diğer spor türleriyle toplumun ilgilenmesinin adeta önüne geçilmektedir. Bu kısır döngü, toplumun farklı sporlara ilgisini sağlayacak spor alanlarının halkın hizmetine sunulmasıyla aşılacaktır."

CHP parti programı tarandığında; spor ve spor alanları hakkında, spora destek verilmesi gerektiği, engelliler içinde spor aracının önemi vurgulandığı görülmektedir (CHP Parti Programı, 2015).

- "Kültürel etkinlikler, herkese spor yapma ve dinlenme alanı olanaklarının sağlanmasını, (s.89)

- Açık ve kapalı Spor sahalarını yaşama geçireceklerdir.(s.90)

-Denizlerimiz, göllerimiz, akarsularımız, sahillerimiz, kumsallarımız, tüm su sporları ortamlarımız ve doğal dinlence alanlarımız" güvenlik, temizlik ve hizmet açısından etkin denetim altında bulundurulacak,

- "Müze, ören yerleri ile milli parkların, dağ ve doğa sporu alanlarının” korunması ve bakımı en üst düzeye çıkarılacak; bu alanlar, gelecek nesillere değerli bir miras olarak bırakılacak şekilde turizme kazandırılacaktır.(s.262)

- Engelliler için spor olanakları yaygınlaştırılacak: Engelliler için uyarlanan spor araçları yaygınlaştırılacak, yerel yönetimler eliyle engellilerimizin bu araçlardan 
yararlanabilmeleri icin gereken tedbirler alınarak toplumda farkındalık yaratıması sağlanacak ve spor yoluyla engellilerin toplumla kucaklaşması kolaylaştırılacaktır (s.327)

-Gençlik ve kültür merkezleri: Eğitim ve gelir düzeyine bakılmaksızın, bütün gençlerimizin yararlanabileceği gençlik ve kültür merkezleri kurulması icin yerel yonetimler desteklenecek, üniversitelerin bünyesinde kurulan kültür merkezi ve spor tesislerinin yaygınlaştırıması sağlanacaktır.(s.331)

-Çağdaş gençlik kampları: Tatillerini hem dinlenmek hem de mesleki ve kültürel birikimlerini geliştirecek şekilde değerlendirmeleri için Çağdaş Gençlik Kampları yaygınlaştırılacak, eğitim ve spor kampları açılarak gençlerimizin yaz tatilleri süresince, zaman ve enerjilerini faydalı bir şekilde değerlendirmeleri sağlanacak, kendi yetenek ve eğilimlerini keşfetmelerine katkıda bulunulacaktır.(s.332)

-Sağlıkı Bir Gençlik Ve Toplum Için Spor Herkes Için Spor (S.333-335)."

MHP 2015 programın 101. sayfasında Gençlik ve spor başlığı altında aşağıdaki paragraf yer almaktadır (MHP Parti Programı, 2015).

- "Milli spor politikası Sporda başarı kadar sevgi, ahlak, disiplin, azim ve gayret gibi erdemler ile toplumsal kaynaşmaya katkının ön plana çıkartılması, her alanda sporcu yetiştirmek için gerekli fiziki, teknolojik ve insan gücü alt yapısının tesis edilmesi milli spor politikamızın esasını oluşturmaktadır. Yerel yönetimler ve gönüllü kuruluşların amatör spor faaliyetleri desteklenecek, özel sektör kuruluşlarının spora daha fazla destek olması özendirilecektir."

Genel olarak araştırma yapılan partilerin tüzükleri ve programları incelendiğinde parti program ve tüzüklerinde spora verilen önem ve değer görülmektedir. Dünya'da ve Türkiye'de spora önem verilmektedir. Sporda önem verilen dalların başında da futbol gelmektedir. Bu durum geniş seyirci kitleleri tarafından takip edilmesinden kaynaklanmaktadır. Günümüzde hemen hemen herkesin futbol sayesinde sosyal bir etkileşim içerisinde olduğu görülmektedir. Diğer bir ifadeyle futbolun toplumsalla ilişkisi ve toplumsal olanın en nihayetinde siyasal olduğu gerçeği siyasilerin ilgisini bu yöne çekmektedir (Mouffe, 2001). Sonuç olarak; sporun toplumsal ve sosyal bir olgu olması, siyasetin de sosyal ve toplumsal olanla ilgilenmesi spor ve siyasetin etkileşimini ortaya koymaktadır.

\section{Tartışma ve Sonuç}

Spor ve siyaset arasındaki etkileşimini Niğde ili örneğinde incelemek için yapılan bu makalede, katılımcıların spor ve siyaset etkileşimine ilişkin görüşlerinden elde edilen bulgular yorumlanmıştır. Bulgulara göre, spor, özellikle fultbol, 
siyasetçilerin seçmenlere ulaşmada, onlarla yakın ilişkiler kurmada, kullandıkları etkileşim araçlarından biri olduğu görülmektedir. Bu nedenle spor, iktidarın ve siyasilerin seçmenlerine ulaşmasında önemli bir aktördür (Karataş, 2014). Siyasilerin seçmenlere ulaşmasında o ülkedeki popüler sporların etkisinin olduğu değerlendirilmektedir. Siyasilerin tuttukları futbol takımlarını açıklamaları, tuttukları futbol takımlarının maçlarına gitmeleri seçmen davranışını olumlu etkileyebilmektedir. Ayrıca milletvekillerinin seçildikleri özellikle küçük ve orta büyüklükteki kentlerdeki futbol takımlarıyla kendilerini özdeşleştirdikleri anlaşılmaktadır. Seçim zamanlarında siyasetçilerin seçim konuşmaları için gittikleri kentlerdeki futbol takımlarının atkılarını taktıkları görülmektedir. Siyasetçiler sporun seçmenlerin üzerindeki etkisini değerlendirerek ulusal ve uluslararası düzeyde başarılar elde etmiş sporcuları milletvekili adayı sonrasında da milletvekili yaparak seçmenlerden destek almayı beklemektedir. Ayrıca, gittikleri seçmen bölgelerinde kentin futbol takımlarının atkılarını takmaları, formalarını giymeleri siyasilerin seçmenlerin sempatisini kazanma çabalarını göstermektedir (İnce, 2016). Bu sembollerle geniş bir seçmen kitlesine mesaj verdikleri düşünülmektedir. Siyasetçiler, sporu seçmenlerine ulaşmada bir araç olarak görmektedir. Futbol gibi popüler spor branşlarının veya organizasyonlarının büyük kitleler tarafından takip edilmesi, amatör veya profosyonel olarak yapılması, milyonlarca insana çok kısa zamanda ve daha düşük maliyetle ulaşılabilmesinden ötürü siyasetçilerin futbola olan ilgisini artırmaktadır. Futbol geçmişimizin siyasetle ilişkisine bakıldığında bir dönem, siyasiler tarafından bir futbol takımının birinci lige yükseltilmesi, futbol takımlarının ligden düşmelerinin kaldırılması, Fenerbahçe Spor Kulübü'nün stadının adının eski başbakan olan Şükrü SARAÇOĞLU, Beşiktaş Jimnastik Kulübü'nün eski stadının adının ise eski Cumhurbaşkanı İsmet INÖNÜ'nün olması, siyasilerin spor ile ilişkilerine örnek olarak verilebilir (Donuk, 2007). Ayrıca Şahin ve İmamaoğlu'nun, 2011'de yaptığı araştırma sonuçlarına göre siyasetçilerin sporun ülkedeki popülerliğine vurgu yaparak, örneklem grubunun sporda siyasetin etkisinin varlığına inandıklarını ifade etttikleri görülmektedir (Şahin ve İmamaoğlu, 2011).

Beinvel'in 2005'te spor ve siyaset ilişkisine dair tezinde, sporun insanların bilinç altında ve karar verme süreçlerinde önemli bir rol oynadığını, sporun insanları etkilediğini, politikacıların ve toplumun sivil aktörlerinin fikir ve düşüncelerini tanıtmak için sporu farklı sebeplerle kullandığı vurgulamaktadır (Beinvel, 2005). Siyasetçiler, zaman zaman kendilerinin ve partilerinin siyasi varlıklarını sürdürebilmek, 
seçmenlerini memnun edebilmek için toplumun dikkatini sportif faaliyetlere yönlendirebilmektedir. Bu durumda göstermektedir ki siyasilerin spor dalı olan futbol ile sadece spora destek vermek amacıyla ilgilenmemektedir. Futbolun seçmenlerin günlük hayatttaki etkisinin farkında olan siyasetçiler bu durumu kullanabilmektedir (Karataş, 2014). Siyasiler, seçim süreci içerisinde gerçekleştirilen sportif faaliyetlere ve seçim bölgelerinde bulunan spor kulüplerine daha fazla ilgili göstererek, bölge halkının sempatisini kazanmak istemektedir (Şahin ve İmamoğu, 2011).

Siyasiler seçmenlerinin sempatisini kazanma çabasında olurken, spor kulüpleri de, kulüplerinin devamlıı̆ını sağlamak, kaliteli sporcu transfer etmek, maçlarını ve antremanlarını yapacağı spor tesisine sahip olmak için maddi kaynağa ve desteğe intiyaç duymaktadır. Bu desteği siyasi çevrelerden yardım alarak sağlamak istedikleri, spor tesisleri için yer tahsis edilmesi, kulüplere stadyum yaptırıması gibi alanlarda devlet desteği aldıkları görülmektedir. Diğer taraftanda spor kulüplerinin uluslararası alanda kazandıkları sportif başarılar, siyasilerin başarısı olarak algılanmakta, spor devlet siyasetinin tanıtımı için etkili bir araç olarak görülmektedir (Ekmekçi ve ark., 2013). Bu anlamda olimpiyatların Türkiye'de yapılması için siyasi otoriterler yoğun çaba harcaması, olimpiyatlarının Türkiye'de yapılması ülkenin 2023 hedefleriyle de paralellik göstermesi, spor ve siyeset arasındaki ilişkiye örnek olarak verilebilir (İnce, 2016).

Siyaseten, ülkeler arasında zaman zaman krizler yaşanabilmektedir. Yaşanan bu krizler sonucunda kriz zamanlarında düzenlenen uluslararası müsabakalarda toplumsal duygular ortaya çıkarak spor müsabakalarını gölgede bırakabilmektedir. Benzer bir biçimde ülkede yaşanan terör olayları sonrasında stadyumlarda atılan sloganlar "Şehitler ölmez vatan bölünmez." spor ve siyaset ilişkilerini ortaya çıkarmaktadır. Ülkemizde Taksim Meydanı'nda yaşanan Gezi Olayları'ndan sonra Beşiktaş Jimnastik Kulübü fanatikleri olarak bilinen Çarşı Grubu'nun Gezi olayları ile ilgili yorumlar yapması, uluslararası maçlarda "Avrupa Avrupa duy sesimizi bu ses Türklerin ayak sesisidir” gibi sloganlar, maçlarda çalınan mehter marşları, spor müsabakalarında milli duygu ve düşüncenin hep var olduğunun göstergesidir. Bu durum, siyaset ile spor arasındaki karşılıkı ilişkinin yoğunlaşmasına yol açmaktadır. Önemli milli maçlarda protokolde siyasilerin maçları izlenmesi, kazanılan başarılardan sonra siyasiler tarafından takım teknik direktörlerinin telefonla aranıp tebrik edilmesi gibi örneklerde spor ve siyaset arasındaki ilişki gözlemlenmektedir. 
Spor başarılarında siyasilerin de anılması, siyasi bir tanıtım aracı olarak görülmektedir. Siyasilerin spor başarıları ile ilgili mesajları, özellikle milli başarıların sonrasında halkın duyguların yoğunlaştığı zamanlarda açıklama ve tebrik mesajları ile siyasiler halkın sevgisini ve sempatisini kazanma fırsatı bulmaktadır. Ülke halkının sevinç ve gurur kaynağı olan sporcu başarıları, ülkedeki siyasi iktidarın başarısının bir yansıması ve göstergesi olarak görülebilmektedir (Saatçioğlu, 2012). Spor olgusu ile siyaset arasındaki etkileşimi, akademisyenler ve milletvekilleri bakış açısından değerlendirmek için yapılan bir araştırmada, sporun, uluslararası spor organizasyonlarında devletlerin itibarını olumlu yada olumsuz etkilediği katılımcılar tarafından, vurgulamıştır (Şahin ve İmamoğu, 2011). Bu anlamda diğer ülkelerde uluslararası alanda elde edilen spor başarılarının o ülkedeki siyaset rejimin bir başarısı olarak gösterildiği, spor başarılarını artırmak için de spor kulüplerine maddi destek sağlandığı görülmektedir. Ayrıca müsabaka birinciliklerinden sonra okunan milli marşlar ülke genelinde birlik ve beraberlik duygusunun artmasına sebep olan olumlu bir araç olarak görülmektedir. Bu başarılar, siyasi çevreler tarafından takip edilerek ödüllendirilirken, başarısızlıklar ise siyasiler tarafından sorgulanmaktadır. Rusya'da düzenlenen Sochi Kış Olimpiyatları'ndaki başarısızlık siyasilerinin dikkatini çekmiş, bu konuda meclise verilen yazılı soru önergesi ile meclis araştırma komisyonu oluşturularak başarısızlığın sebepleri araştırılmıştır (www.haberler.com, 2014).

Sonuç olarak; spor, geçmişten günümüze kadar bütün toplumların çeşitli amaçlar ile yaptığı sosyal bir olgu olarak karşımıza çıkmaktadır. Siyasetin ise toplumsal bir olgu olması, toplumun üzerinde bir etkiye sahip olması ve toplumu ilgilendirmesi sebebiyle siyasetçileri spora doğru çekmektedir. Siyasilerin sporu seçmenlerine ulaşmada bir araç olarak kullanmaları giderek formalleşmektedir. Bunu devletler, ulusal ve uluslararası alanda toplumla olan ilişkilerini düzenlemede siyaset ve ideolojinin bir aracı olarak kullanmaktadır (Şahin ve İmamoğlu, 2014).

Araştırma sonucunda katılımcılar genel olarak spor ve siyaset arasında bir etkileşimin varığını kabul etmektedir. Bununla birlikte bu etkileşimin sadece siyasiler tarafından talep edilmediği, aynı zamanda spor kulüplerinin de amaçları doğrultusunda siyasilerden destek beklentileri oldukları vurgulanmaktadır. Ancak yapılacak destekler, alınacak yardımlar ne olursa olsun, sporun yarışma ruhuna, etiğine aykırı olmaması, kayırmacılığın yapılmaması beklenirken, rekabet, fair-play, adalet, dürüstlük gibi erdemlilik ifadelerinin önemi vurgulanmaktadır. Bu araştırma 
belirli bir bölgede yapılmasından dolayı sınırlılıkları bulunmaktadır. Araştırma ülke genelindeki siyasileride kapsayacak şekilde gerçekleştirilirse daha kapsamlı ve farklı sonuçlara ulaşılabilir.

\section{Kaynaklar}

Alkan, H. (2018). Siyaset Bilimine Giriş, İstanbul, İstanbul Üniversitesi Yayınları.

Altunışık R., Coşkun R., Bayraktaroğlu S. ve Yıldıım E. (2012). Sosyal Bilimlerde Araştırma Yöntemleri: SPSS Uygulamalı, Sakarya, Sakarya Yayıncılık.

Arnauld, P.,Riordan, J. (2006). Sport and International Politics, London.

Basım, N.H. ve Argan, M. (2009). Spor Yönetimi, Ankara, Detay Yayıncılık.

Beinvel, S. (2005). Sport and Politics: A study of the relationshipbetween International Politics and Football, Linköpings Universitet MSC Programme in International and European Relations Master Thesis, 78.

Chien, Y.L., Ping, C.L.,Hui F.N. (2009). Therorizm the Role of Sport in state-Politics, International Journal of Sport and exercise Science 1 (1): 23-32

Donuk, B. (2007). Liderlik ve Spor, İstanbul, Ötüken Yayınevi.

Dursun, D. (2013). Siyaset Bilimi, Eskişehir, Anadolu Üniversitesi Yayınları.

Ekmekçi, R. (2016). Spor Yönetimi, Eskişehir, Anadolu Üniversitesi Yayınları.

Ekmekçi Y.A., Ekmekçi R., İrmiş A. (2013). Küreselleşme ve Spor Endüstrisi, Pamukkale Journal of Sport Science, Vol 1 No1, 91-117.

Gürbüz, S., Şahin, F. (2018). Sosyal Bilimlerde Araştırma Yöntemleri (5.Basım). Ankara, Seçkin Yayıncılık.

Houlihan, B. (1991). The Goverment and Politics of Sport, Londra: Routledge.

İnce, M. (2016). Spor ile Siyasetin İlişkisi Üzerine Bir Analiz; Sporu Siyasete Alet Etmek, Karabük Üniversitesi Sosyal Bilimler Enstitüsü Dergisi, 6 (2), 456-464.

Karasar, N. (2006). Bilimsel Araştırma Yöntemleri, (15. Baskı). Ankara, Nobel Yayın Dağıtım.

Konter, E. (2006). Sporda Karşılaşma Psikolojisi, Ankara, Nobel Yayın Dağıtım,16.

Karataş, Ö. (2014). Türkiye'de Futbol ve Siyaset İlişkisi, İnönü Üniversitesi, Beden Eğitimi ve Spor Bilimleri Dergisi, 1(2), 39-47.

Lui, H.(2003) State, Sport And Politics: Sport Policy İn Republic Of China/Taiwan 1973-2002, Through A Strategic Relations Approach, Loughborough University (United Kingdom), ProQuest Dissertations Publishing, 2003. U171894. 
Mardin, Ş. (2006). Türkiye'de Toplum ve Siyaset, İstanbul, İletişim Yayınları, 45.

Mouffe, C. (2001). Demokratik Paradoks (Çeviren: A.C.AŞKIN), Ankara, Epos Yayıncılık.

Nakip M., Yaraş E. (2017). SPSS Uygulamalı Pazarlamada Araştırma Teknikleri, Seçkin, Ankara.

Parti Programı, CHP, (2015). https://www.chp.org.tr/wp-content/uploads/chpprogram. pdf Erişim Tarihi:14.10.2015.

Parti Programı, MHP, (2015). https://www.mhp.org.tr/usr_img/_mhp2007/.../ mhp_ parti_programi_2009_opt.pdf, Erişim Tarihi:14.10.2015.

Parti Tüzüğü, AKP, (2015). http://www.akparti.org.tr/site/akparti/parti-tuzugu, Erişim Tarihi:14.10.2015.

Parti Tüzüğü, CHP, (2015). https://www.chp.org.tr/Assets/dosya/chp-tuzugu-2015-0112.pdf, Erişim Tarihi:14.10.2015.

Parti Tüzüğü, MHP, (2015). http://www.mhp.org.tr/htmldocs/mhp/tuzuk/mhp/ siyasi _parti_tuzugu.html, Erişim Tarihi:14.10.2015.

Saatçioğlu, C. (2012). Ekonomi ve Spor: Ekonomik Gelişmenin Uluslararası Sportif Başarı Üzerindeki Etkisi, Yalova Üniversitesi Hukuk Fakültesi Dergisi(1), 27-42 Şahin, H.M. (2003). Sporda Şiddet ve Saldırganlık, Ankara, Nobel Dağıtım Yayıncılık. Şahin M.Y., İmamoğu A.F. (2011). Akademisyenlerin ve Milletvekillerinin Spor Siyaset Etkileşimine Yönelik Görüşleri, Gazi Beden Eğitimi ve Spor Bilimleri Dergisi. Cilt: XVI Sayı:2, 25-44.

Türksoy A. (2010). Futbolda Liderlik ve Antrenörlük, Ankara, Nobel Dağıtım Yayıncılık.

Türk Dil Kurumu (TDK), (2015). (http://tdk.gov.tr/index.php?option =com_gts\&arama =gts\&guid=TDK.GTS.51c4193281b9c6.28209814), Erişim tarihi: 05.10.2015, Yetim, A.A. (2011). Sosyoloji ve Spor, Ankara, Berikan Yayınevi.

https://www.haberler.com/soci-ye-iddiasiz-katilim-meclis-te-5645085-haberi/ Erişim tarihi: 08.02.2014.

Şahin M.Y., İmamoğu A.F. (2011).

Victor D.C. (2009). A Theroy of Sport and Politics, The International Journal of the History of Sport 26 (11):1581-1610. 